Vol II. No. 1, September 2017, hlm. 8 - 15

Available online at www.jurnal.una.ac.id/indeks/jmp

\title{
PERBEDAAN KEMAMPUAN PENALARAN DAN PEMECAHAN MASALAH MELALUI PEMBELAJARAN KONTEKSTUAL DALAM KURIKULUM 2013
}

\author{
Eva Margaretha Saragih \\ Pendidikan Matematika Universitas Asahan, Jl. Jenderal Ahmad Yani Kisaran \\ Email : margarethaevasaragih@gmail.com
}

\begin{abstract}
The aim of this study are to examine: (1) Determine whether there are differences in mathematical reasoning ability and mathematical problem solving ability among junior high school students learning to use a contextual approach to the regular learning. (2) To see if there is interaction between contextual learning approach with the ability to beginning students to increase students reasoning ability and problem solving abilities. This research was a quasi experiment. The populations of this study were all students of class VII-1 in SMP Negeri 6 and SMP Negeri 2 Kisaran city. The sample selected was a class VII-1 (experimental class) and class VII-4 (control class) in SMP Negeri 6 Kisaran. The sample selected was a class VII-1 (experimental class) and class VII-4 (control class) in SMP Negeri 2 Kisaran city.The instruments used are: a test of reasoning ability and problem solving tests. Data analysis was performed with ANAKOVA. The main results of this study are: (1) There are differences in mathematical reasoning ability and problem solving ability among students of SMP Negeri 6 and SMP Negeri 2 Kisaran given regular contextual learning and learning, (2) There is no interaction between teaching approaches used with initial abiity to increase students mathematical reasoning ability and problem solving ability.
\end{abstract}

Keywords : Contextual Learning, Reasoning, Problem Solving, Interaction.

\begin{abstract}
Abstrak
Tujuan penelitian ini adalah: (1) Untuk mengetahui apakah terdapat perbedaan kemampuan pemecahan masalah dan kemampuan penalaran siswa yang menerima pembelajaran kontekstual dengan yang menerima pembelajaran konvensional. (2) Untuk melihat apakah terdapat interaksi antara pendekatan pembelajaran kontekstual dengan kemampuan awal siswa terhadap peningkatan kemampuan penalaran dan pemecahan masalah siswa. Penelitian ini merupakan penelitian semi eksperimen. Populasi penelitian ini adalah seluruh siswa kelas VII SMP Negeri 6 dan SMP Negeri 2 Kisaran. Sampel yang dipilih adalah kelas VII-1 (kelas eksperimen), dan kelas VII-4 (kelas kontrol) pada SMP Negeri 6 Kisaran sedangkan pada SMP Negeri 2 Kisaran sampel yang dipilih adalah kelas VII-1 (kelas eksperimen) dan kelas VII-4 (kelas kontrol). Instrumen yang digunakan terdiri dari: tes kemampuan penalaran dan tes kemampuan pemecahan masalah. Analisis data dilakukan dengan ANAKOVA. Hasil utama penelitian ini adalah: (1) Terdapat perbedaan kemampuan penalaran dan pemecahan masalah matematik siswa SMP Negeri 6 dan SMP Negeri 2 Kisaran yang diberi pembelajaran kontekstual dengan pembelajaran konvensional. (2) Tidak terdapat interaksi antara pembelajaran yang digunakan dengan kemampuan awal terhadap kemampuan penalaran dan pemecahan masalah matematik siswa.
\end{abstract}

Kata kunci : Pembelajaran Kontekstual, Penalaran, Pemecahan Masalah, Interaksi. 


\section{Gurnal}

\section{MATEMATICS PAEDAGOGIC}

Vol II. No. 1, September 2017, hlm. 8 - 15

Available online at www.jurnal.una.ac.id/indeks/jmp

Salah satu cabang ilmu pengetahuan yang turut dalam memajukan pendidikan adalah matematika, oleh karena itu mempelajari matematika sangat penting. Matematika memiliki peranan penting dalam berbagai aspek kehidupan. Banyaknya permasalahan dan kegiatan dalam hidup yang harus diselesaikan dengan menggunakan ilmu matematika seperti menghitung, mengukur dan lain-lain. Selain itu peran matematika dewasa ini semakin penting, karena banyaknya informasi yang disampaikan dalam bahasa matematika seperti tabel, grafik, diagram dan persamaan.

Berdasarkan standar kompetensi yang termuat dalam kurikulum tersebut maka pembelajaran matematika di sekolah harus dapat menyiapkan siswa untuk memiliki kemampuan pemecahan masalah dan penalaran matematika sebagai bekal untuk menghadapi tantangan perkembangan dan perubahan.

Pembelajaran kontekstual merupakan pendekatan yang dikembangkan dengan tujuan agar pembelajaran lebih produktif dan bermakna, tanpa harus mengubah kurikulum dan tatanan yang ada. Dengan siswa diajak bekerja dan mengalami, siswa akan mudah memahami konsep suatu materi dan nantinya diharapkan siswa dapat menggunakan daya nalarnya untuk menyelesaikan masalah-masalah yang ada. Pada kenyataannya, siswa mengalami banyak kesulitan pada materi tertentu dalam mata pelajaran matematika. Kesulitan yang dialami dikarenakan kurangnya pemahaman dan ketertarikan siswa pada pelajaran matematika juga belum diterapkannya pembelajaran kontekstual dalam pembelajaran matematika di sekolah. Salah satu faktor yang mengakibatkan siswa kurang tertarik pada pelajaran matematika adalah suasana kelas yang pasif serta adanya persepsi siswa terhadap matematika sebagai pelajaran yang sulit. Hal ini mengakibatkan kecenderungan kelas menjadi tegang. Dengan kata lain, guru tidak memberikan kesempatan kepada siswa untuk mengkontruksikan pengetahuan matematika yang akan menjadi milik siswa. Dengan kondisi yang demikian, siswa belum mampu memaksimalkan penalaran matematis siswa untuk memahami konsep matematika. Karena itulah diperlukan guru yang aktif dan kreatif dalam kegiatan pembelajaran sehingga siswa dapat menguasai materi dan mencapai tujuan pembelajaran yang ditetapkan.

\section{METODE}

Populasi penelitian ini adalah semua siswa kelas VII dari sekolah yang berakreditasi B yang ada di Kabupaten Asahan yang berjumlah 8 sekolah. Alasan dipilihnya sekolah dengan level menengah dikarenakan level kemampuan akademik siswanya heterogen (Saragih, 2007: 59). Sekolah yang berasal dari level tinggi (akreditas A) cenderung memiliki hasil belajar yang lebih baik, tetapi baiknya itu bisa terjadi bukan akibat baiknya pembelajaran yang dilakukan, demikian juga dengan sekolah yang berasal dari level rendah (akreditas C), cenderung hasil belajarnya akan kurang (jelek) dan kurangnya itu bisa terjadi bukan akibat kurang baiknya pembelajaran yang dilakukan.

Sampel penelitian dipilih secara acak (cluster random sampling). Hal ini sesuai dengan pendapat Ruseffendi (1978: 78) bahwa salah satu cara memilih sampel yang mewakili populasinya adalah cara random sederhana, yaitu bila setiap anggota dari populasinya mempunyai kesempatan yang sama untuk dipilih. Lebih lanjut Ruseffendi 


\section{Gurnal}

\section{MATEMATICS PAEDAGOGIC}

Vol II. No. 1, September 2017, hlm. 8 - 15

Available online at www.jurnal.una.ac.id/indeks/jmp

(1998: 79) mengatakan bahwa salah satu cara memperoleh sampel secara random adalah dengan memberi nomor anggota populasi pada kertas-kertas kecil, kemudian digulung, dimasukkan ke suatu tempat lalu diundi diambil sebanyak yang diperlukan. Sehingga pemilihan sampel dalam penelitian ini adalah dengan penomoran tiap sekolah pada kertas lalu dilakukan undian. Sampel yang terpilih yaitu SMP Negeri 6 Kisaran dan SMP Negeri 2 Kisaran

Dari SMP Negeri 6 diambil siswa kelas VII-1 sebagai kelas pembelajaran kontekstual dan siswa kelas VII-4 sebagai kelas pembelajaran konvensional. Dari SMP Negeri 2 Kisaran diambil kelas VII-1 sebagai kelas pembelajaran kontekstual dan kelas VII-4 sebagai kelas pembelajaran konvensional. Alasan terpilihnya siswa SMP Negeri 6 dan SMP Negeri 2 sebagai sampel dalam penelitian ini adalah karena sekolah tersebut belum pernah menerapkan pembelajaran kontekstual.

Rancangan eksperimen yang digunakan dalam penelitian ini adalah pretest posttest control group design. Dalam rancangan ini terdapat dua kelompok yang dipilih secara random, kemudian diberi pretest untuk mengetahui sejauh mana kesiapan siswa menerima pembelajaran dan pretest digunakan untuk menyetarakan pengetahuan awal kedua kelompok sedangkan postest digunakan untuk mengukur kemampuan penalaran dan kemampuan pemecahan masalah matematis siswa setelah diberi perlakuan.

Desain dalam penelitian ini menggunakan kelompok kontrol pretest dan postest yang dinyatakan sebagai berikut pada tabel :

\begin{tabular}{|l|c|c|c|}
\hline $\begin{array}{l}\text { Kelompok } \\
\text { Perlakuan } \\
\text { Test }\end{array}$ & $\begin{array}{c}\text { Pre- } \\
\mathrm{n}\end{array}$ & $\begin{array}{c}\text { Perlakua } \\
\text { Test }\end{array}$ \\
\hline Kontekstual & $O_{1}$ & $X_{1}$ & $O_{2}$ \\
\hline $\begin{array}{l}\text { Konvension } \\
\text { al }\end{array}$ & $O_{1}$ & $\mathrm{X} 2$ & $O_{2}$ \\
\hline
\end{tabular}

Sumber: Ruseffendi (2005)

Keterangan:

A : Pemilihan sampel secara acak

X1 : Perlakuan pembelajaran kontekstual pada kelas eksperimen

$\mathrm{X} 2$ :Perlakuan pembelajaran konvensional pada kelas kontrol

$O_{1}$ : Pretes pada kelompok eksperimen dan kelas kontrol

$\mathrm{O}_{2}$ : Postes pada kelompok eksperimen dan kelas kontrol.

\section{HASIL DAN PEMBAHASAN}

\section{a. Uji Normalitas}

Sebelum data dianalisis, terlebuh dahulu diuji normalitas data sebagai syarat analisis kuantitatif. Pengujian ini dilakukan untuk melihat apakah data hasil tes penalaran matematika siswa berdistribusi secara normal pada kelompok pembelajaran kontekstual dan kelompok pembelajaran konvensional. Setelah dilakukan pengolahan data hasil tes penalaran matematik siswa, dapat disimpulkan bahwa tes pengetahuan awal kelompok pembelajaran kontekstual dan kelompok pembelajaran konvensional berdistribusi normal. Setelah dilakukan maka dapat disimpulkan bahwa tes pengetahuan awal pada kedua kelompok tersebut berdistribusi normal. Dari hasil 
Vol II. No. 1, September 2017, hlm. 8 - 15

Available online at www.jurnal.una.ac.id/indeks/jmp

perhitungan tes awal kemampuan penalaran logis siswa pada kelas kontrol diperoleh: $L_{\text {hitung }}=0,097$ dan $L_{\text {tabel }}=\frac{0,886}{\sqrt{68}}=0.1074$. Ternyata $L_{\text {hitung }} \leq L_{\text {tabel }}$ artinya data terdistribusi normal. Dan untuk kemampuan penalaran logis pada kelas eksprimen diperoleh: $\quad L_{\text {hitung }}=0,095$ dan $L_{\text {tabel }}=\frac{0,886}{\sqrt{68}}=0.1074$. Ternyata $L_{\text {hitung }} \leq$ $L_{\text {tabel }}$ artinya data terdistribusi normal.

Sedangkan pada tes akhir kemampuan penalaran logis siswa pada kelas kontrol diperoleh: $\quad L_{\text {hitung }}=0,095$ dan $L_{\text {tabel }}=\frac{0,886}{\sqrt{68}}=0.1074$. Ternyata $L_{\text {hitung }} \leq$ $L_{\text {tabel }}$ artinya data terdistribusi normal. Dan kemampuan penalaran logis siswa pada kelas ekperimen diperoleh: $L_{\text {hitung }}=0,100$ dan $\quad L_{\text {tabel }}=\frac{0,886}{\sqrt{68}}=0.1074 . \quad$ Ternyata $L_{\text {hitung }} \leq L_{\text {tabel }}$ artinya data terdistribusi normal.

\section{b. Uji Homogenitas Data}

Uji homogenitas adalah pengujian sama tidaknya variabel-variabel dua buah distribusi atau lebih. Pengujian homogenitas ini menggunakan uji varians dua buah peubah bebas. Untuk pengujian homogenitas dalam penelitian ini diambil sampel di kelas pembelajaran kontekstual sebanyak 68 siswa dan kelas pembelajaran konvensional sebanyak 68 siswa. Telah dihitung sebelumnya bahwa sampel di kedua kelas dalam pretes adalah berdistribusi normal.

Varians tes awal kemampuan penalaran matematik di kelas eksprimen
$\left(S_{E}^{2}\right)=2,399$ dan kelas konrol $\left(S_{K}^{2}\right)=2,178$. Maka diperoleh: $F_{\text {hitung }}=\frac{S_{\text {besar }}^{2}}{S_{\text {kecil }}^{2}}=\frac{2,399}{2,178}=$ 1,10 dan $F_{\text {tabel }}=3,14$, pembilang $=2$ dan penyebut $=(68-2)$ dan taraf signifikansinya $=5 \%$. Karena $F_{\text {hitung }}<F_{\text {tabel }}$ maka $H_{0}$ ditolak artinya data tes awal kemampuan penalaran adalah homogen. Varians tes akhir kemampuan penalaran matematik di kelas eksprimen $\left(S_{E}^{2}\right)=3,000$ dan kelas konrol $\left(S_{K}^{2}\right)=2,386$. Maka diperoleh: $F_{\text {hitung }}=\frac{S_{\text {besar }}^{2}}{S_{\text {kecil }}^{2}}=\frac{3,000}{2,386}=1,257$ dan $F_{\text {tabel }}=3,14$, pembilang $=2$ dan penyebut $=$ ( 68-2 ) dan taraf signifikansinya $=5 \%$. Karena $F_{\text {hitung }}<F_{\text {tabel }}$ maka $H_{0}$ ditolak artinya data tes awal kemampuan penalaran adalah homogen.

\section{c. Model Regresi Linier}

Dari data hasil uji awal dan akhir siswa diperoleh persamaan regresi untuk kelas kontrol adalah: $\quad Y_{k}=5,161+0,309 X_{K}$ (perhitungan terlampir pada lampiran E17) dan persamaan regresi untuk kelas eksperimen: $Y_{E}=7,83+0,213 X_{E}$.

\section{Uji Independensi dan Uji Linieritas}

Model regresi linier $\mathrm{Y}$ atas $\mathrm{X}$ untuk kelompok kontrol adalah $Y_{K}=a+b X_{K}$, dengan a dan $\mathrm{b}$ adalah estimator utuk $\theta_{1}$ dan $\theta_{2}$ dalam persamaan $\mathrm{Y}=\theta_{1}+\theta_{2} \mathrm{X}$. Sedangkan untuk kelas eksperimen adalah $Y_{E}=a+b X_{E}$, dengan a dan $\mathrm{b}$ adalah estimator utuk $\theta_{3}$ dan $\theta_{4}$ dalam persamaan $\mathrm{Y}$ $=\theta_{3}+\theta_{4} \mathrm{X}$. 
Gurnal

\section{MATEMATICS PAEDAGOGIC}

Vol II. No. 1, September 2017, hlm. 8 - 15

Available online at www.jurnal.una.ac.id/indeks/jmp

\section{Uji Independensi Kelas Kontrol}

Menguji keberarartian koefisien regresi tersebut dirumuskan hipotesis sebagai berikut: $H_{0}: \theta_{2}=0$ dan $H_{a}: \theta_{2} \neq$ 0 . Untuk menguji hipotesis tersebut digunakan analisis varians dengan menggunakan rumus dan kriteria yang telah ditetapkan.Dari hasil perhitungan untuk kemampuan penalaran matematik diperoleh $\mathrm{F}^{*}=5,74$ dan berdasarkan Tabel F, untuk $\alpha$ $=\quad 5 \%$ diperoleh: $F_{(1-0,05),(1,66)}=F_{(0,95),(1,66)}=3,99 .{\text { Berarti } \mathrm{F}^{*} \geq}^{*}$ $F_{(0,95),(1,66)} \cdot H_{0}$ ditolak dan diterima $H_{a}$. Dan ada pengaruh signifikansi hasil uji awal kemampuan penalaran matematik siswa terhadap hasil uji akhir siswa.

\section{Uji Linieritas Persamaan Regresi Kelas Kontrol}

Akan diuji kecocokan model regresi linier untuk kemampuan penalaran matematik:

$Y_{K}=5,162+0,310 \mathrm{X}$ dengan hipotesis:

$H_{0} \quad$ : Model regresi adalah linier

$H_{a} \quad$ : Model regresi adalah tidak linier

Untuk menguji hipotesis di atas dilakukan dengan analisis varians dengan menggunakan statistik-F dengan rumus dan kriteria yang telah ditetapkan. Untuk kemampuan penalaran matematik kelas kontrol diperoleh $F^{*}=0,24$, untuk $\alpha=5 \%$ diperoleh: $\quad F_{(1-\alpha, c-2, n-c)}=F_{(0,95,9,57)}=2,05$. Berarti $\quad F^{*}<F_{(0,95,12,26)} \cdot H_{0}$ diterima atau model regresi kelas kontrol adalah linier.

\section{Uji Indepedensi Kelas Eksperimen}

Berdasarkan data hasil uji awal dengan uji akhir siswa kelas eksperimen untuk kemampuan penalaran diperoleh: persamaan regresi kemampuan penalaran matematik $Y_{E}=7,814+0,217 X_{E}$. Untuk menguji keberartian koefisien persamaan regresi tersebut dirumuskan hipotesis sebagai berikut:

$$
H_{0}: \theta_{4}=0 \text { dan } H_{a}: \theta_{4} \neq 0
$$

Untuk menguji hipotesis di atas dilakukan dengan analisis varians dengan menggunakan statistik- $F$ dengan rumus dan kriteria yang telah ditetapkan.

Dari hasil perhitungan pada Tabel 4.9, diperoleh $\mathrm{F}^{*}=1,75$ dan berdasarkan Tabel $\mathrm{F}$, untuk $\alpha=5 \%$ diperoleh: $\mathrm{F}_{(1-\alpha, 1: n-2)}=$ $\mathrm{F}_{(0,95,1,66)}=3,99 . \quad$ Berarti $\quad \mathrm{F}^{*} \geq$ $\mathrm{F}_{(0,95,1,38)} \cdot \mathrm{H}_{0}$ ditolak dan diterima $\mathrm{H}_{a}$. Artinya ada pengaruh positif (signifikansi) hasil tes awal kemampuan penalaran matematika siswa $(\mathrm{X})$ terhadap hasil tes akhir siswa (Y) untuk pembelajaran kontekstual.

\section{Uji Linieritas Persamaan Regresi Kelas Eksperimen}

Akan diuji kecocokan model regresi linier untuk kemampuan pemecahan masalah $\mathrm{Y}_{E}=7,814+0,217 \mathrm{X}_{E}$ dengan hipotesis:

$\mathrm{H}_{0}$ : Model regresi adalah linier

$\mathrm{H}_{a}$ : Model regresi adalah tidak linier

Untuk menguji hipotesis di atas dilakukan dengan analisis varians dengan menggunakan statistik-F dengan rumus dan kriteria yang ditetapkan. 
Vol II. No. 1, September 2017, hlm. 8 - 15

Available online at www.jurnal.una.ac.id/indeks/jmp

Untuk kemampuan penalaran matematika siswa diperoleh $\mathrm{F}^{*}=0,27 \mathrm{dan}$ berdasarkan Tabel F, untuk $\alpha=5 \%$ diproleh: $\quad \mathrm{F}_{(1-\alpha, c-2, n-c)}=\mathrm{F}_{(0,95,10,56)}=2,00$. Berarti $\mathrm{F}^{*}<\mathrm{F}_{(0,95,10,56)} \cdot \mathrm{H}_{0}$ diterima atau model regresi kelas model pembelajaran langsung adalah linier. Artinya ada hubungan antara hasil tes awal dengan tes akhir siswa kelas eksperimen dapat ditunjukkan dengan model regresi linier dengan persamaan regresi untuk kemampuan penalaran $\mathrm{Y}_{E}=7,814+$ $0,217 \mathrm{X}_{E}$. Dengan kata lain, hubungan antara hasil tes awal dengan tes akhir siswa kelas kontekstual dapat dinyatakan dengan model regresi linier atau model regresi.

\section{d. Uji Kesamaan Dua Model Regresi}

Untuk menguji kesamaan dua model regresi kelas eksperimen dan kelas kontrol digunakan analisis varians dengan menggunakan statistik F, Untuk menguji kesamaan dua model tersebut dirumuskan hipoteis sebagai berikut:

$\mathrm{H}_{0}: \theta_{1}=\theta_{3}$ dan $\theta_{2}=\theta_{4}$ (kedua model regresi sama)

$\mathrm{H}_{1}: \theta_{1} \neq \theta_{3}$ dan $\theta_{2} \neq \theta_{4} \quad$ (kedua model regresi tidak sama).

\section{f. Uji Kesejajaran Dua Model Regresi Linier}

Jika dalam pengujian kesamaan dua model regresi di atas $\mathrm{H}_{0}$ ditolak (model regresi tidak sama), sehingga dilanjutkan dengan menguji dua kesejajaran model regresi. Menguji kesejajaran model regresi linier untuk kelompok kontrol dan eksperimen digunakan analisis kovarians dengan menggunakan statistik $\mathrm{F}$ dengan rumus dan kriteria yang ditetapkan.

Dari hasil perhitungan pada kemampuan penalaran matematik siswa diperoleh nilai $\mathrm{F}^{*}=0,21159$ dan berdasarkan Tabel F, untuk $\alpha=5 \%$ diperoleh $\quad \mathrm{F}_{(1-\alpha, 1: n-2)}=\boldsymbol{F}_{(\mathbf{0 . 9 5}, \mathbf{1}, \mathbf{1 2 8})}=3,92$. Berarti $\mathrm{F}^{*}<\mathrm{F}_{(0,95,1,132)}$ maka $\mathrm{H}_{0}$ diterima dengan taraf signifikan 5\%. Hal ini berarti bahwa kedua model regresi linier untuk kelas pembelajaran kontekstual dan kelas pembelajaran konvensional adalah sejajar. Oleh karena kedua model regresi tidak sama (tidak berimpit) dan sejajar maka dapat disimpulkan bahwa ada perbedaan hasil belajar kelompok pembelajaran kontekstual dan kelompok pembelajaran konvensional.

\section{g.Analisis Kovarians dengan Modifikasi Analisis Varians}

Berdasarkan hasil uji linieritas dan kesejajaran model regresi dipenuhi maka untuk menguji perbedaan kemampuan penalaran matematika siswa yang diajar dengan pembelajaran kontekstual dengan kemampuan penalaran matematika siswa yang diajar dengan pembelajaran konvensional dapat dianalisis dengan anakova sebagai modifikasi analisis varians. Untuk itu dirumuskan hipotesis analisisnya dengan menduga jarak kedua garis regresi linier kelompok kontrol dan kelompok eksperimen dari setiap skor hasil tes akhir dari rata-rata skor tes akhir kelompok kontrol dan skor tes akhir kelompok eksperimen. Hipotesisnya adalah sebagai berikut:

$$
\begin{aligned}
& \mathrm{H}_{0}: \theta_{4}=\theta_{2} \\
& \mathrm{H}_{a}: \theta_{4} \neq \theta_{2}
\end{aligned}
$$




\section{Gurnal}

\section{MATEMATICS PAEDAGOGIC}

Vol II. No. 1, September 2017, hlm. 8 - 15

Available online at www.jurnal.una.ac.id/indeks/jmp

Dari hasil perhitungan untuk kemampuan penalaran matematika siswa diperoleh

$\mathrm{F}^{*}=\frac{\operatorname{MSTR}_{(a d j)}}{M S E_{(a d j)}}=\frac{118,923}{7,052}=4,79$ dan berdasarkan Tabel F, untuk $\alpha=5 \%$ diperoleh $\mathrm{F}_{(0,95,1,132)}=3,91$. Berarti $\mathrm{F}^{*} \geq \mathrm{F}$ $(0,95,1: 132)$ sehingga $\mathrm{H}_{0}: \mathrm{r}_{1}=\mathrm{r}_{2}=0$ ditolak. Hal ini berarti ada perbedaan yang signifikan antara kemampuan penalaran matematika siswa yang dikenai perlakuan pembelajaran kontekstual dengan siswa yang dikenai pembelajaran konvensional.

\section{SIMPULAN}

Terdapat perbedaan kemampuan penalaran matematika antara siswa SMP Negeri Kisaran yang pembelajaran kontekstual dengan siswa yang diberi pembelajaran konvensional. Hal ini terlihat dari hasil analisis covarians (ANACOVA) untuk $F_{\text {hitung }}$ adalah 4,79 lebih besar dari $F_{\text {tabel }}$ adalah 3,91 dan konstanta regresi untuk pembelajaran kontekstual adalah 7,814 lebih besar dari pembelajaran konvensional yaitu 5,612.Sedangkan pada kemampuan penalaran pada aspek silogisme lebih baik dari aspek yang lain dengan ratarata 1,985. Sementara analogi merupakan aspek yang lain dengan ratarata sebesar 1,985, sementara untuk analogi merupakan aspek yang kurang baik dari aspek lainnya dengan rata-rata 1,426 .

Tidak terdapat interaksi antara model pembelajaran dengan kemampuan awal matematika siswa (tinggi, sedang, rendah) terhadap penalaran matematik siswa. Dengan demikian, tidak ada kontribusi secara bersama-sama yang disumbangkan oleh model pembelajaran dengan kemampuan awal siswa terhadap kemampuan penalaran matematik siswa. Namun, peningkatan kemampuan penalaran matematik siswa pada pembelajaran kontekstual lebih baik dibandingkan dengan pembelajaran konvensional untuk kemampuan awal siswa tinggi, sedang dan rendah.

Proses penyelesaian jawaban siswa dengan mengunakan pembelajaran kontekstual lebih baik dibandingkan dengan pembelajaran konvensional. Hal ini ditunjukkan dengan jawaban siswa dalam menyelesaikan tes kemampuan pemecahan masalah dan penalaran matematis lebih baik pada kelas pembelajaran kontekstual dibandingkan dengan pembelajaran konvensional.

Berdasarkan kesimpulan yang diperoleh, maka peneliti memberikan saran untuk tindakan lebih lanjut sebagai berikut : Bagi guru matematika, Pembelajaran kontekstual pada pembelajaran matematika yang menekankan kemampuan penalaran matematika siswa dapat dijadikan sebagai salah satu alternatif untuk menerapkan pembelajaran matematika yang innovatif khususnya dalam mengajarkan materi aritmatika sosial.

Perangkat pembelajaran yang dihasilkan dapat dijadikan sebagai bandingan bagi guru dalam mengembangkan perangkat pembelajaran matematika dengan pembelajaran kontekstual pada pokok bahasan aritmatika sosial.

Diharapkan guru perlu menambah wawasan tentang teori-teori pembelajaran dan model pembelajaran yang inovatif agar dapat melaksanakannya dalam pembelajaran matematika. 


\section{DAFTAR RUJUKAN}

Ansari, B. I. (2009). Komunikasi Matematika Konsep dan Aplikasi. Banda Aceh : Yayasan Pena.

Istiqomah, N. (2007). Upaya Meningkatkan Kemampuan Komunikasi Matematika Siswa Kelas IV SD Negeri Sekaran 2 pada Materi Pokok Kelipatan Persekutuan Terkecil (KPK) dan Pecahan dengan Menggunakan Pembelajaran Kurikulum Berbasis Kompetensi (KBK) Bercirikan Pendayagunaan Alat Peraga dan Pendampingan Tahun Pelajaran 2006/2007. Skripsi Universitas Negeri Semarang : Tidak diterbitkan. Tersedia online

http://www.ask.com/web.universitasnegeri-semarang (diakses 10 Mei 2013)

Lie, A. (2008). Cooperative Learning. Jakarta : PT Gramedia.

NCTM. (2000).Mathematic Assesment A Practical Handbook. Virginia, The National Council of Teacher Mathematic Inc.

Saragih, S. 2007. Mengembangkan Kemampuan Berpikir Logis dan Komunikasi Matematika Siswa Sekolah Menengah Pertama Melalui Pendekatan Matematika Realistik. Disertasi pada PPS, Bandung: UPI tidak diterbitkan.

Trianto, 2010. Model Pembelajaran Terpadu : Konsep, Strategi dan Implementasinya Dalam Kurikulum Tingkat satuan Pendidikan (KTSP). Jakarta : Bumi Aksara. 